\title{
Nutrient Removal from Olive Trees by Fruit Yield and Pruning
}

\author{
Ricardo Fernández-Escobar ${ }^{1}$, Miguel A. Sánchez-Zamora, \\ Jorge M. García-Novelo, and Concepción Molina-Soria \\ Departamento de Agronomía, Universidad de Córdoba, Edificio C 4, Campus \\ Universitario de Rabanales, Ctra. Madrid-Cádiz km. 396, 14071 Córdoba, \\ Spain
}

\section{Additional index words. Olea europaea, leaf analysis, olive fertilization}

\begin{abstract}
The determination of nutrient removal from olive orchards could be of interest to estimate tree consumption and to provide information about the amount of nutrients to be applied when leaf analysis indicates the need for fertilization. In this work, nutrient removal from yield and pruning was determined from the control plots of two olive orchards located in different locations, in which two long-term experiments dealing with nitrogen fertilization were conducted. The trees from these plots received only potassium fertilizers during the 7 years of the experiments, because the previous season's leaf analysis showed that the other nutrients were always above the threshold of sufficiency. Potassium was the most abundant element in the harvested fruits with an average of $4.42 \mathrm{~g} \cdot \mathrm{kg}^{-1}$ fresh fruit, which represents more than $50 \%$ of the mineral composition of the olive fruit, whereas calcium was the more abundant element in the pruning material with an average of $12.0 \mathrm{~g} \cdot \mathrm{kg}^{-1}$ and $6.87 \mathrm{~g} \cdot \mathrm{kg}^{-1}$, depending on the location, which represents more than $50 \%$ of the mineral composition of the pruning material. Nitrogen was the second more abundant element in both fruits $\left(2.87 \mathrm{~g} \cdot \mathrm{kg}^{-1}\right)$ and pruning material $\left(6.87\right.$ and $5.40 \mathrm{~g} \cdot \mathrm{kg}^{-1}$, depending on the location), representing $\approx 35 \%$ of the mineral composition of both fruit and pruning material. The other nutrients were removed only in very small amounts. Expressed per hectare, the amounts of nutrients removed annually were: $57.9 \mathrm{~kg} \cdot \mathrm{ha}^{-1}$ per year calcium $(\mathrm{Ca}), 54.4 \mathrm{~kg} \cdot \mathrm{ha}^{-1}$ per year nitrogen $(\mathrm{N}), 45.5 \mathrm{~kg} \cdot \mathrm{ha}^{-1}$ per year potassium $(\mathrm{K})$, $6.87 \mathrm{~kg} \cdot \mathrm{ha}^{-1}$ per year phosphorus $(\mathrm{P}), 3.79 \mathrm{~kg} \cdot \mathrm{ha}^{-1}$ per year magnesium $(\mathrm{Mg}), 0.12 \mathrm{~kg} \cdot \mathrm{ha}^{-1}$ per year copper $(\mathrm{Cu}), 0.11 \mathrm{~kg} \cdot \mathrm{ha}^{-1}$ per year boron $(\mathrm{B}), 0.08 \mathrm{~kg} \cdot \mathrm{ha}^{-1}$ per year manganese, and $0.05 \mathrm{~kg} \cdot \mathrm{ha}^{-1}$ per year zinc $(\mathrm{Zn})$. These data show that olive trees remove small amounts of nutrients and, therefore, the need for fertilization is relatively low.
\end{abstract}

The current fertilization practice in olive (Olea europaea L.) orchards usually leads to excessive fertilizer applications. These are unnecessary to maintain high productivity and growth, may contribute to environmental degradation (Fernández-Escobar et al., 2009a; Giménez et al., 2001), and also cause negative effects on the tree and the crop (FernándezEscobar et al., 2006, 2008). The low cost of fertilizers in relation to the crop value together with the lack of knowledge of nutrient use of mature trees contribute to maintain such a cultural practice.

Under a rational and responsible use of fertilizers, a nutrient should be supplied only when there are proofs that it is needed to assure normal growth and productivity and when economic response to fertilizer application is

Received for publication 3 Nov. 2014. Accepted for publication $23 \mathrm{Jan} .2015$.

This research was supported by the Ministerio de Educación y Ciencia, Spain, Projects No. AGF96-1116, AGL2001-2447, AGL2004-02387, and AGL2005-03273, and European Regional Development Fund (ERDF).

We acknowledge Instituto Andaluz de Investigación y Formación Agraria, Pesquera, Alimentaria y de la Producción Ecológica (IFAPA) for technical facilities during the development of this research.

${ }^{1}$ To whom reprint requests should be addressed; e-mail rfernandezescobar@uco.es. mineralization of the organic matter, reuse of nutrients, nutrient supplied by the irrigation water and rainfall, among other factors, explains the inefficacy of this fertilization strategy. Thus, an estimation of nutrient removal could be of interest to estimate tree consumption and to provide some information about the amount of a nutrient to be applied if leaf analysis indicates the need for fertilization. That is very valuable information to consider in the fertilization program. The aim of the present work was to determine nutrient removal from two olive orchards located in different environmental conditions.

\section{Materials and Methods}

The data were obtained from two longterm experiments dealing with the optimization of $\mathrm{N}$ fertilization in olive orchards conducted from 1994 to 2006 in two different locations. A detailed description of the experiments can be found in FernándezEscobar et al. (2009a). One experiment was located in Cabra, Province of Córdoba, Spain (lat. $37.28^{\circ} \mathrm{N}$, long. $4.26^{\circ} \mathrm{W}$ ), which has a mean annual rainfall of $702 \mathrm{~mm}$ and a mean annual temperature of $16^{\circ} \mathrm{C}$. The soil is clay loamy to sandy clay loamy with organic matter ranging from $0.8 \%$ to $1.0 \%$ and a $\mathrm{pH}$ ranging from 8.1 to 8.3 . Non-irrigated, 12-year-old 'Picual' olive trees spaced at $7 \mathrm{~m}$ $\times 7 \mathrm{~m}$ were selected for the experiment. The second experiment was located in Mengibar, Province of Jaen, Spain (lat. $37.58^{\circ} \mathrm{N}$, long. $3.48^{\circ} \mathrm{W}$ ), which has a mean annual rainfall of $524 \mathrm{~mm}$ and a mean annual temperature of $17{ }^{\circ} \mathrm{C}$. The soil is silty clay loam with an average organic matter of $1 \%$ and a $\mathrm{pH}$ ranging from 8.2 to 8.3 . Non-irrigated, 50-year-old 'Picual' olive trees spaced at $12 \mathrm{~m} \times 12 \mathrm{~m}$ were selected. In both experiments, the experimental design consisted of several treatments of $\mathrm{N}$ fertilization applied in four blocks and four trees per plot. The control plots of both experiments were the treatments selected for the present work. The trees of these plots were fertilized only when the previous season's leaf analysis indicated the need for fertilization, which only occurred with $\mathrm{K}$ as usual in rainfed olives (Fernández-Escobar et al., 1994; Parra et al., 2003). When that happened, a solution of $2 \%$ to $4 \% \mathrm{~K}_{2} \mathrm{SO}_{4}$ was sprayed to the trees to reach adequate levels (Restrepo-Díaz et al., 2008).

Leaf nutrient concentrations were determined from July samples of fully expanded, mature leaves taken from the middle to basal portion of non-bearing current-season's shoots. Approximately 100 leaves were collected from each plot, placed in paper bags, and stored in a portable cooler. Once in the laboratory, leaves were washed with $0.03 \%$ Triton $\mathrm{X}-100$, rinsed with deionized water, dried at $80^{\circ} \mathrm{C}$ for $48 \mathrm{~h}$, ground, and stored in an oven at $60^{\circ} \mathrm{C}$ until analysis.

Trees were harvested mechanically, and the total fresh weight of fruit per experimental tree was measured. Nutrients removed by the crop were estimated from fruit samples of $2 \mathrm{~kg}$ per plot taken at harvest from 1997 to 
2003 in Cabra's experiment. Fruits were washed and rinsed. Pulp and stones were removed separately from each fruit, dried at $80^{\circ} \mathrm{C}$ for $48 \mathrm{~h}$, ground, and stored until analysis.

Concerning pruning, trees in Cabra were subjected to light pruning every 2 years and every 4 years to renewal pruning in Mengibar often combined with a light pruning in between. All pruning material from each control plot was collected in both locations at the end of the experiment in Winter 2006. Leaves, smaller than $6-\mathrm{cm}$ diameter branches, and bigger than $6-\mathrm{cm}$ diameter branches were separated, weighed, and a sample from each group was taken for analysis. At the laboratory, samples were washed, rinsed, dried at 80 ${ }^{\circ} \mathrm{C}$ for $72 \mathrm{~h}$, ground, and placed in an oven at $60{ }^{\circ} \mathrm{C}$ until analysis. Branches samples were cut into small pieces before drying.

For all samples, $\mathrm{N}$ was determined with a EuroVector EA3000 CHN analyzer (EuroVector S.p.A., Milan, Italy) by the Dumas procedure (Dumas, 1831). For other element determinations, the stored samples were ashed in a muffle furnace at $600{ }^{\circ} \mathrm{C}$ for $12 \mathrm{~h}$ and dissolved in $0.1 \mathrm{~N} \mathrm{HCl}$. Total $\mathrm{P}$ was determined by colorimetry using the method described by Murphy and Riley (1962). Boron was determined in the extract by colorimetry (Greweling, 1976). The remaining elements (K, Mg, Ca, $\mathrm{Zn}$, $\mathrm{Mn}$, iron, and $\mathrm{Cu}$ ) were measured using an atomic absorption spectrophotometer, PerkinElmer 1.100 B (PerkinElmer, Shelton, CT).
Means and the SES were obtained on the data.

\section{Results}

Leaf analysis indicates that the majority of leaf nutrient concentrations was above the threshold of sufficiency in both locations during the 6 years of study, except for $\mathrm{K}$ (Table 1). This element showed values below the sufficiency level of $0.8 \%$ but above the deficiency level of $0.4 \%$ most of the years. Consequently, $\mathrm{K}$ was applied to the experimental trees when leaf $\mathrm{K}$ concentration dropped below the sufficiency level, allowing maintaining leaf $\mathrm{K}$ concentration above deficiency. No other nutrient was applied during the experimental period.

Fruit removal of mineral nutrients was determined only in Cabra. In this experiment, the average yield was of $40.3 \mathrm{~kg} /$ tree, equivalent to $8.2 \mathrm{t} \cdot \mathrm{ha}^{-1}$ (Table 2). This orchard showed a slightly pronounced alternate bearing during the period of study, probably because the trees were young. Potassium was the most abundant element in the harvested fruits with an average of 4.42 $\mathrm{g} \cdot \mathrm{kg}^{-1}$ fresh fruit, which represents more than $50 \%$ of the mineral composition of the olive fruit (Table 2). The second most abundant element was $\mathrm{N}$ with an average of $2.87 \mathrm{~g} \cdot \mathrm{kg}^{-1}$ fresh fruit. That value represents almost $35 \%$ of the mineral composition of the fruit. The amounts of P $\left(0.49 \mathrm{~g} \cdot \mathrm{kg}^{-1}\right.$ fresh fruit), $\mathrm{Ca}\left(0.29 \mathrm{~g} \cdot \mathrm{kg}^{-1}\right.$ fresh fruit), and $\mathrm{Mg}$ (0.16 $\mathrm{g} \cdot \mathrm{kg}^{-1}$ fresh fruit) represent all together $\approx 11 \%$ of the mineral composition and the rest of elements $\approx 1 \%$.

Pruning material was composed of leaves of different ages, smaller than 6-cm diameter branches, and bigger than $6-\mathrm{cm}$ diameter branches. Although most of the nutrients were removed by the leaves when expressed in grams per kilogram of fresh organ (Table 3), the nutrient content removed by the branches was important when expressed in amount per hectare (Table 4). Calcium was the most abundant element in the pruning material with values of $12.0 \mathrm{~g} \cdot \mathrm{kg}^{-1}$ and $6.87 \mathrm{~g} \cdot \mathrm{kg}^{-1}$ of fresh material in Cabra and Mengibar, respectively. These values represent more than $50 \%$ of the mineral composition of the pruning material. Nitrogen was the second most abundant element in the pruning material (6.64 and $5.40 \mathrm{~g} \cdot \mathrm{kg}^{-1}$ of fresh material in Cabra and Mengibar, respectively), representing 30\% to $41 \%$ of the mineral composition of pruning. Very small amounts of other nutrients were removed by pruning, from 18 to $29 \mathrm{~kg} \cdot \mathrm{ha}^{-1}$ of all these elements together, depending on the location (Table 4).

Total nutrients removed annually by fruit yield and pruning were determined in Cabra's experiment (Table 5). Calcium $\left(57.9 \mathrm{~kg} \cdot \mathrm{ha}^{-1}\right.$ per year), $\mathrm{N}$ (54.4 $\mathrm{kg} \cdot \mathrm{ha}^{-1}$ per year), and $\mathrm{K}$

Table 1. Leaf nutrient concentration of July samples. ${ }^{z}$

\begin{tabular}{|c|c|c|c|c|c|c|c|c|c|c|c|c|}
\hline \multirow[b]{3}{*}{ Concn (DW) } & \multicolumn{6}{|c|}{ Cabra's expt. } & \multicolumn{6}{|c|}{ Mengibar's expt. } \\
\hline & \multicolumn{6}{|c|}{$\mathrm{Yr}$} & \multicolumn{6}{|c|}{$\mathrm{Yr}$} \\
\hline & 1998 & 1999 & 2000 & 2001 & 2002 & 2003 & 1998 & 1999 & 2000 & 2001 & 2002 & 2003 \\
\hline$\overline{\mathrm{N}(\%)}$ & 1.53 & 1.41 & 1.53 & 1.54 & 1.45 & 1.42 & 1.59 & 1.35 & 1.36 & 1.32 & 1.38 & 1.35 \\
\hline P (\%) & 0.14 & 0.09 & 0.10 & 0.10 & 0.10 & 0.09 & 0.14 & 0.09 & 0.11 & 0.11 & 0.11 & 0.11 \\
\hline K (\%) & 0.85 & 0.67 & 0.75 & 0.59 & 0.65 & 0.49 & 0.88 & 0.51 & 0.82 & 0.47 & 0.78 & 0.63 \\
\hline $\mathrm{Ca}(\%)$ & 1.26 & 1.68 & 1.83 & 1.53 & 1.28 & 1.56 & 1.31 & 1.68 & 1.82 & 1.43 & 1.41 & 1.31 \\
\hline $\operatorname{Mg}(\%)$ & 0.10 & 0.13 & 0.18 & 0.14 & 0.10 & 0.14 & 0.10 & 0.14 & 0.22 & 0.15 & 0.13 & 0.15 \\
\hline $\mathrm{Mn}(\mathrm{ppm})$ & 30.5 & 47.9 & 44.2 & 27.4 & 24.8 & 27.7 & 35.7 & 50.6 & 54.9 & 36.9 & 27.4 & 35.2 \\
\hline $\mathrm{Zn}(\mathrm{ppm})$ & 15.1 & 13.1 & 17.4 & 15.7 & 15.3 & 10.1 & 12.1 & 12.8 & 20.0 & 14.7 & 16.9 & 15.5 \\
\hline $\mathrm{Cu}(\mathrm{ppm})$ & 23.2 & 45.3 & 17.1 & 9.5 & 18.9 & 21.0 & 11.7 & 58.7 & 31.5 & 10.2 & 12.0 & 28.8 \\
\hline $\mathrm{B}(\mathrm{ppm})$ & 71.1 & 26.6 & 42.3 & 37.6 & 44.0 & 32.7 & 74.3 & 31.4 & 35.2 & 45.9 & 46.7 & 38.5 \\
\hline
\end{tabular}

${ }^{\mathrm{z}}$ The SEs have been omitted to clarify the table. Most of the values were $\approx 1 \%$ of the mean values.

$\mathrm{DW}=$ dry weight; $\mathrm{N}=$ nitrogen; $\mathrm{P}=$ phosphorus; $\mathrm{K}=$ potassium; $\mathrm{Ca}=$ calcium; $\mathrm{Mg}=$ magnesium; $\mathrm{Mn}=\mathrm{manganese} ; \mathrm{Zn}=$ zinc $; \mathrm{Cu}=$ copper; $\mathrm{B}=$ boron .

Table 2. Yield and fruit removal of mineral nutrients in Cabra's experiment. ${ }^{z}$

\begin{tabular}{|c|c|c|c|c|c|c|c|c|}
\hline & \multicolumn{8}{|c|}{$\mathrm{Yr}$} \\
\hline & 1997 & 1998 & 1999 & 2000 & 2001 & 2002 & 2003 & $\overline{A v g}$ \\
\hline$\overline{\text { Yieldy }(\mathrm{kg} / \text { tree })}$ & 48.7 & 23.5 & 29.5 & 46.9 & 46.0 & 40.5 & 47.1 & 40.3 \\
\hline Yield $\left(\mathrm{t} \cdot \mathrm{ha}^{-1}\right)$ & 9.9 & 4.8 & 6.0 & 9.6 & 9.4 & 8.3 & 9.6 & 8.2 \\
\hline \multicolumn{9}{|c|}{ Nutrients removed (weight per $\mathrm{kg}$ of fresh organ) } \\
\hline $\mathrm{N}(\mathrm{g})$ & 2.80 & 2.95 & 2.58 & 4.87 & 2.80 & 1.99 & 2.14 & 2.87 \\
\hline $\mathrm{P}(\mathrm{g})$ & 0.76 & 0.82 & 0.68 & 0.28 & 0.34 & 0.27 & 0.30 & 0.49 \\
\hline $\mathrm{K}(\mathrm{g})$ & 4.51 & 4.45 & 3.23 & 3.88 & 5.04 & 5.10 & 4.76 & 4.42 \\
\hline $\mathrm{Ca}(\mathrm{g})$ & 0.29 & 0.21 & 0.37 & 0.33 & 0.31 & 0.10 & 0.40 & 0.29 \\
\hline $\operatorname{Mg}(\mathrm{g})$ & 0.19 & 0.19 & 0.20 & 0.15 & 0.16 & 0.09 & 0.15 & 0.16 \\
\hline $\mathrm{Mn}(\mathrm{mg})$ & 3.89 & 2.42 & 2.50 & 1.88 & 2.92 & 3.34 & 2.16 & 2.73 \\
\hline $\mathrm{Zn}(\mathrm{mg})$ & 7.34 & 3.81 & 3.29 & 4.00 & 4.90 & 3.13 & 2.93 & 4.20 \\
\hline $\mathrm{Cu}(\mathrm{mg})$ & 6.45 & 5.65 & 4.41 & 5.85 & 4.96 & 4.04 & 6.00 & 5.34 \\
\hline $\mathrm{Fe}(\mathrm{mg})$ & 7.65 & 10.60 & 9.18 & - & - & - & - & 9.14 \\
\hline B (mg) & 14.00 & - & - & 13.10 & 9.72 & 7.32 & 10.60 & 10.95 \\
\hline
\end{tabular}

${ }^{2}$ The SEs have been omitted to clarify the table. Most of the values were around or below $10 \%$ of the mean values.

${ }^{\mathrm{y}}$ Orchard density of 204 tree/ha.

$\mathrm{N}=$ nitrogen; $\mathrm{P}=$ phosphorus; $\mathrm{K}=$ potassium; $\mathrm{Ca}=$ calcium; $\mathrm{Mg}=$ magnesium; $\mathrm{Mn}=$ manganese $\mathrm{Zn}=\mathrm{zinc} ; \mathrm{Cu}=\mathrm{copper} ; \mathrm{Fe}=$ iron; $\mathrm{B}=$ boron. 


\begin{tabular}{|c|c|c|c|c|c|c|c|c|}
\hline & \multicolumn{4}{|c|}{ Cabra's expt. ${ }^{y}$} & \multicolumn{4}{|c|}{ Mengibar's expt. ${ }^{y}$} \\
\hline & \multirow[b]{2}{*}{ Leaves } & \multicolumn{2}{|c|}{ Branches } & \multirow[b]{2}{*}{ Pruning material $^{\mathrm{x}}$} & \multirow[b]{2}{*}{ Leaves } & \multicolumn{2}{|c|}{ Branches } & \multirow[b]{2}{*}{ Pruning material ${ }^{\mathrm{x}}$} \\
\hline & & $\varnothing \leq 6 \mathrm{~cm}$ & $\varnothing>6 \mathrm{~cm}$ & & & $\varnothing \leq 6 \mathrm{~cm}$ & $\varnothing>6 \mathrm{~cm}$ & \\
\hline Weight (kg/tree) & 17.3 & 28.2 & 0 & 45.5 & 63.5 & 132.2 & 145.9 & 341.6 \\
\hline \multicolumn{9}{|c|}{ Nutrients removed (weight per kg of fresh organ) } \\
\hline$N(g)$ & 10.3 & 4.37 & 0 & 6.64 & 10.03 & 4.64 & 4.07 & 5.40 \\
\hline$P(g)$ & 0.90 & 0.43 & 0 & 0.61 & 0.11 & 0.04 & 0.007 & 0.04 \\
\hline $\mathrm{K}(\mathrm{g})$ & 3.07 & 1.32 & 0 & 1.98 & 1.01 & 0.29 & 0.24 & 0.40 \\
\hline $\mathrm{Ca}(\mathrm{g})$ & 15.9 & 9.58 & 0 & 12.0 & 14.8 & 6.20 & 4.03 & 6.87 \\
\hline $\operatorname{Mg}(\mathrm{g})$ & 0.87 & 0.32 & 0 & 0.53 & 0.86 & 0.27 & 0.13 & 0.32 \\
\hline $\mathrm{Mn}(\mathrm{mg})$ & 22.5 & 7.45 & 0 & 13.2 & 27.3 & 8.04 & 4.07 & 9.92 \\
\hline $\mathrm{Zn}(\mathrm{mg})$ & 9.25 & 2.48 & 0 & 5.05 & 8.76 & 2.88 & 2.37 & 3.75 \\
\hline $\mathrm{Cu}(\mathrm{mg})$ & 27.2 & 12.8 & 0 & 18.5 & 10.2 & 0.76 & 0.27 & 2.30 \\
\hline $\mathrm{B}(\mathrm{mg})$ & 4.62 & 3.90 & 0 & 4.17 & 4.90 & 3.47 & 2.13 & 3.16 \\
\hline
\end{tabular}

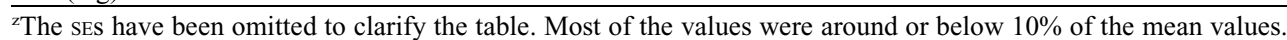

${ }^{\mathrm{y}}$ Orchard density of 204 tree/ha in Cabra and 69 tree/ha in Mengibar. Trees subjected every 2 years to light pruning in Cabra and every 4 years to renewal pruning in Mengibar.

Include leaves and branches.

$\mathrm{N}=$ nitrogen; $\mathrm{P}=$ phosphorus; $\mathrm{K}=$ potassium; $\mathrm{Ca}=$ calcium; $\mathrm{Mg}=$ magnesium; $\mathrm{Mn}=$ manganese $\mathrm{Zn}=\mathrm{zinc} ; \mathrm{Cu}=\mathrm{copper} ; \mathrm{B}=$ boron.

Table 4. Mineral nutrients removed by pruning per hectare. ${ }^{\mathrm{z}}$

\begin{tabular}{|c|c|c|c|c|c|c|c|c|}
\hline & \multicolumn{4}{|c|}{ Cabra's expt. $^{y}$} & \multicolumn{4}{|c|}{ Mengibar's expt. ${ }^{y}$} \\
\hline & \multirow[b]{2}{*}{ Leaves } & \multicolumn{2}{|c|}{ Branches } & \multirow[b]{2}{*}{ Pruning material $^{\mathrm{x}}$} & \multirow[b]{2}{*}{ Leaves } & \multicolumn{2}{|c|}{ Branches } & \multirow[b]{2}{*}{ Pruning material } \\
\hline & & $\overline{\varnothing \leq 6 \mathrm{~cm}}$ & $\varnothing>6 \mathrm{~cm}$ & & & $\overline{\varnothing \leq 6 \mathrm{~cm}}$ & $\varnothing>6 \mathrm{~cm}$ & \\
\hline Weight (kg/tree) & 17.3 & 28.2 & 0 & 45.5 & 63.5 & 132.2 & 145.9 & 341.6 \\
\hline \multicolumn{9}{|c|}{ Nutrients removed $\left(\mathrm{kg} \cdot \mathrm{ha}^{-1}\right)$} \\
\hline $\mathrm{N}$ & 36.5 & 25.2 & 0 & 61.7 & 43.9 & 42.3 & 41.0 & 127.2 \\
\hline $\mathrm{P}$ & 3.20 & 2.48 & 0 & 5.68 & 0.47 & 0.41 & 0.08 & 0.96 \\
\hline $\mathrm{K}$ & 10.8 & 7.57 & 0 & 18.4 & 4.41 & 2.61 & 2.38 & 9.40 \\
\hline $\mathrm{Ca}$ & 56.0 & 55.1 & 0 & 111.1 & 64.8 & 56.5 & 40.5 & 161.8 \\
\hline $\mathrm{Mg}$ & 3.09 & 1.87 & 0 & 4.96 & 3.77 & 2.43 & 1.30 & 7.50 \\
\hline $\mathrm{Mn}$ & 0.08 & 0.04 & 0 & 0.12 & 0.12 & 0.07 & 0.04 & 0.23 \\
\hline $\mathrm{Zn}$ & 0.03 & 0.01 & 0 & 0.04 & 0.04 & 0.03 & 0.02 & 0.09 \\
\hline $\mathrm{Cu}$ & 0.10 & 0.07 & 0 & 0.17 & 0.04 & 0.007 & 0.003 & 0.05 \\
\hline B & 0.02 & 0.02 & 0 & 0.04 & 0.02 & 0.03 & 0.02 & 0.07 \\
\hline
\end{tabular}

${ }^{\mathrm{z}}$ The SES have been omitted to clarify the table. Most of the values were around or below $10 \%$ of the mean values.

${ }^{y}$ Orchard density of 204 tree/ha in Cabra and 69 tree/ha in Mengibar. Trees subjected every 2 years to light pruning in Cabra and every 4 years to renewal pruning in Mengibar.

'Include leaves and branches.

$\mathrm{N}=$ nitrogen; $\mathrm{P}=$ phosphorus $\mathrm{K}=$ potassium $; \mathrm{Ca}=$ calcium $; \mathrm{Mg}=$ magnesium; $\mathrm{Mn}=$ manganese $; \mathrm{Zn}=\mathrm{zinc} ; \mathrm{Cu}=\mathrm{copper} ; \mathrm{B}=$ boron.

Table 5. Nutrients removed annually in Cabra's experiment. ${ }^{z}$

\begin{tabular}{lccc}
\hline Nutrient & $\begin{array}{c}\text { Fruit removal }^{\mathrm{y}} \\
\left(\mathrm{kg} \cdot \mathrm{ha}^{-1} \text { per year }\right)\end{array}$ & $\begin{array}{c}\text { Pruning removal } \\
\left(\mathrm{kg} \cdot \mathrm{ha}^{-1} \text { per year }\right)\end{array}$ & $\begin{array}{c}\text { Total nutrient removed }^{\mathrm{x}} \\
\left(\mathrm{kg} \cdot \mathrm{ha}^{-1} \text { per year }\right)\end{array}$ \\
\hline $\mathrm{N}$ & 23.6 & 30.8 & 54.4 \\
$\mathrm{P}$ & 4.03 & 2.84 & 6.87 \\
$\mathrm{~K}$ & 36.3 & 9.20 & 45.5 \\
$\mathrm{Ca}$ & 2.38 & 55.5 & 57.9 \\
$\mathrm{Mg}$ & 1.31 & 2.48 & 3.79 \\
$\mathrm{Mn}$ & 0.02 & 0.06 & 0.08 \\
$\mathrm{Zn}$ & 0.03 & 0.02 & 0.05 \\
$\mathrm{Cu}$ & 0.04 & 0.08 & 0.12 \\
$\mathrm{~B}$ & 0.09 & 0.02 & 0.11 \\
\hline
\end{tabular}

${ }^{\mathrm{z}}$ The SEs have been omitted to clarify the table. Most of the values were around or below $10 \%$ of the mean values.

${ }^{\mathrm{y}}$ Average of 7 years

${ }^{\mathrm{x}}$ Taking into account the biennial pruning.

$\mathrm{N}=$ nitrogen; $\mathrm{P}=$ phosphorus $; \mathrm{K}=$ potassium; $\mathrm{Ca}=$ calcium; $\mathrm{Mg}=$ magnesium; $\mathrm{Mn}=$ manganese; $\mathrm{Zn}=$ zinc; $\mathrm{Cu}=$ copper; $\mathrm{B}=$ boron.

(45.5 $\mathrm{kg} \cdot \mathrm{ha}^{-1}$ per year) were the most abundant nutrients removed from this olive orchard. Calcium was mainly removed with the pruning material, $\mathrm{K}$ with the fruits, and $\mathrm{N}$ with both materials. Phosphorous and $\mathrm{Mg}$ were removed in small amounts, 6.87 and $3.79 \mathrm{~kg} \cdot \mathrm{ha}^{-1}$ per year, respectively. Micronutrients were removed in very small amounts, ranging from
$0.05 \mathrm{~kg} \cdot \mathrm{ha}^{-1}$ per year for $\mathrm{Zn}$ to $0.12 \mathrm{~kg} \cdot \mathrm{ha}^{-1}$ per year for $\mathrm{Cu}$.

\section{Discussion}

According to the fertilization program followed in this experiment, a nutrient was only applied when the previous season's leaf analysis indicated that leaf nutrient concentration of that nutrient was below the sufficiency threshold recorded in the reference values compiled by Fernández-Escobar (2010). Consequently, only K was applied during the experiment. Potassium is the main cause of nutritional disorder in rainfed olive orchards (Fernández-Escobar et al., 1994), even when they are established in soils with high $\mathrm{K}$ content (Parra et al., 2003), and it is usually recommended to be applied under these environmental conditions (RestrepoDíaz et al., 2008). Although N showed values below $1.4 \%$ in Mengibar's experiment, established as the deficiency threshold (Beutel et al., 1983), recent reports have questioned this level because no reduction in yield or growth was observed with lower concentrations (Fernández-Escobar et al., 2009a), suggesting that deficiency of mature trees could be found below $1.2 \%$. Therefore, nutrients removed by the crop were not influenced by external applications of mineral elements, except for K. Although the application of $\mathrm{K}$ fertilizers could have influenced the accumulation of $\mathrm{K}$ in fruits, this does not explain that more than $50 \%$ of the mineral composition of 
olive fruits is $\mathrm{K}$ in the present work. In fact, it is well known that olive is a fruit with high $\mathrm{K}$ content (Bustan et al., 2013; FernándezHernández et al., 2010) as occurs also in other fruit tree species such as peach (El Jendoubi et al., 2013; Huett and Stewart, 1999) and apple (Faqi et al., 2008; Palmer and Dryden, 2006).

If $\mathrm{K}$ was the nutrient removed in larger amounts in the fruit, $\mathrm{Ca}$ was removed in greater amounts in the pruning material. This effect was also reported in peaches (El Jendoubi et al., 2013) and probably occurs in other fruit tree species, but few studies have been conducted to determine $\mathrm{Ca}$ removal in pruning materials of fruit trees. In any case, these results are consistent with the fact that part of the $\mathrm{Ca}$ is firmly bound in structures, and a high proportion is often located in cell walls (Hawkesford et al., 2012). In the Mediterranean region, $\mathrm{Ca}$ deficiency is uncommon, because many olive orchards are grown in calcareous soils. Calcium may represent a nutritional problem only in regions with non-calcareous soils or in acid soils, where $\mathrm{Ca}$ availability to plants is limited.

Nitrogen was the third element removed in large amounts and was located in both fruit and pruning material. It is well known that after carbon, $\mathrm{N}$ is the element required in larger amounts by plants because is a constituent of many metabolites. In woody plants, $\mathrm{N}$ is stored in roots and in the bark of shoots and trunks (Titus and Kang, 1982). In olive, like in other evergreen trees, $\mathrm{N}$ is also stored in leaves (Klein and Weinbaum, 1984). However, N represents a nutritional problem in olive-growing as a result of overuse of $\mathrm{N}$ fertilizers rather than unavailability (Fernández-Escobar, 2011), as has been also reported for other fruit crops (Weinbaum et al., 1992). In a previous work, FernándezEscobar et al. (2012) studied the $\mathrm{N}$ balance in these two orchards. They found that after 7 years, there were more $\mathrm{N}$ inputs in the orchards than outputs, resulting in a positive $\mathrm{N}$ balance that explains why leaf $\mathrm{N}$ concentrations remained above deficiency for many years without $\mathrm{N}$ application.

The other nutrients were removed only in small amounts. Phosphorus was removed approximately eight times less than the above mentioned nutrients and $\mathrm{Mg} \approx 14$ times less. Micronutrients were removed in very small amounts (500 to 1000 times less than the major nutrients). This fact indicates that these elements may constitute a nutritional problem only in situations of low availability as a result of soil blockage.

The results obtained in the present work indicate that only small amounts of nutrients were removed by fruit yield and pruning. These results are in agreement with those obtained by Rodrigues et al. (2012) in 1 year, although the amounts of nutrients removed per hectare were lower because the trees were very young. This could explain why there was no need for fertilization during the years studied with the exception of $\mathrm{K}$ as has been mentioned, suggesting that nutrient availability in these orchards could compensate nutrient removal.
The amount of nutrients removed was similar to those reported for other fruit tree species such as peaches (El Jendoubi et al., 2013) and apples (Palmer and Dryden, 2006). In comparison, larger amounts of nutrients are removed by annual crops (Faqi et al., 2008; Rochester, 2007).

It is obvious that the nutrition of woody perennial trees differs in many ways from that of annual herbaceous plants. The presence of storage organs and the ability to reuse nutrients to support the new growth are characteristics of perennial plants that differ from the annual ones. That could suggest that fertilization needs of the woody plants could be lower than that of annuals. However, the current practice of fruit tree nutrition is to apply more nutrients than the amount removed by harvest. Weinbaum et al. (1992) reported that in California orchards, $\mathrm{N}$ fertilization rates are often three to five times higher than the $\mathrm{N}$ removed with the harvest. Also, Faqi et al. (2008) indicated that farmers in China applied 60 times more $\mathrm{N}$ and 33 times more $\mathrm{P}$ in apple trees than what was removed by harvest. Considering the amounts of nutrient removal presented in this work, similar results were obtained for the Mediterranean olive orchards (Fernández-Escobar, 2008). In Spain, for instance, olive farmers increased in more than 10 times the cost of fertilization compared with a fertilization program based on leaf analysis without an increase of yield or vegetative growth but causing negative effects in oil quality (Fernández-Escobar et al., $2009 \mathrm{~b}$ ). Taking into account that as a result of the alternate bearing cycle of the olive crop, fruit removal in the "off" years will be lower than the reported data in the present work and that the actual practice in many olive orchards is to leave a mulch of pruning residues; nutrient removal from an olive orchard will be significantly lower than the values reported here.

In conclusion, olive trees remove small amounts of mineral nutrients that seem to be provided through soil nutrient availability because no need for fertilization was indicated by leaf analysis during the 7 years of the experiment, except for $\mathrm{K}$, which was the major constituent of the mineral composition of the fruit. Calcium and $\mathrm{N}$ were the other nutrients removed in greater amounts but there was no need to apply these nutrients. The other elements were removed only in small amounts. The data presented here can help to determine the amount of a nutrient to be applied when leaf analysis indicates the need for fertilization.

\section{Literature Cited}

Beutel, J., K. Uriu, and O. Lilleland. 1983. Leaf analysis for California deciduous fruits, p. 1517. In: Reisenauer, H.M. (ed.). Soil and plant tissue testing in California. University of California, Bull. 1879.

Bustan, A., A. Avni, U. Yermiyahu, A. Ben-Gal, J. Riov, R. Erel, I. Zipori, and A. Dag. 2013. Interactions between fruit load and macroelement concentrations in fertigated olive (Olea europaea L.) trees under arid saline conditions. Sci. Hort. 152:44-55.
Dumas, J.B.A. 1831. Procedes de l'analyse organic. Annales de Chimie et de Physique 247:198-213.

El Jendoubi, H., J. Abadía, and A. Abadía. 2013. Assessment of nutrient removal in bearing peach trees (Prunus persica L. Batsch) based on whole tree analysis. Plant Soil 369:421-437.

Faqi, W., L. Haibin, S. Baosheng, W. Jian, and W.J. Gale. 2008. Net primary production and nutrient cycling in an apple orchard-annual crop system in the Loess Plateau, China: A comparison of Qinguan apple, Fuji apple, corn and millet production systems. Nutr. Cycl. Agroecosyst. 81:95-105.

Faust, M. 1979. Evolution of fruit nutrition during the 20th century. HortScience 14:321-325.

Fernández-Escobar, R. 2008. Olive fertilization practices in the Mediterranean region. Olivae 109:13-22.

Fernández-Escobar, R. 2010. Fertilisation, p. 267 297. In: Barranco, D., R. Fernández-Escobar, and L. Rallo (eds.). Olive growing. RIRDC, Barton ACT, Australia.

Fernández-Escobar, R. 2011. Use and abuse of nitrogen in olive fertilization. Acta Hort. 888:249-257.

Fernández-Escobar, R., G. Beltrán, M.A. SánchezZamora, J. García-Novelo, M. Aguilera, and M. Uceda. 2006. Olive oil quality decreases with nitrogen over-fertilization. HortScience 41:215219.

Fernández-Escobar, R., J.M. García.Novelo, C. Molina-Soria, and M.A. Parra. 2012. An approach to nitrogen balance in olive orchards. Sci. Hort. 135:219-226.

Fernández-Escobar, R., T. García-Barragán, and M. Benlloch. 1994. Estado nutritivo de las plantaciones de olivar en la provincia de Granada. ITEA 90:39-49.

Fernández-Escobar, R., L. Marin, M.A. SánchezZamora, J.M. García-Novelo, C. Molina-Soria, and M.A. Parra. 2009a. Long-term effects of N fertilization on cropping and growth of olive trees and on $\mathrm{N}$ accumulation in soil profile. Eur. J. Agron. 31:223-232.

Fernández-Escobar, R., M.A. Parra, C. Navarro, and O. Arquero. 2009b. Foliar diagnosis as a guide to olive fertilization. Span. J. Agr. Res. 7:212-223.

Fernández-Escobar, R., A. Ortiz-Urquiza, M. Prado, and H.F. Rapoport. 2008. Nitrogen status influence on olive tree flower quality and ovule longevity. Environ. Expt. Bot. 64:113-119.

Fernández-Hernández, A., G. Beltrán, and R. Fernández-Escobar. 2010. Contenido de potasio en fruto de Olea europaea L. Agricultura 925:32-35

Giménez, C., E. Díaz, F. Rosado, A. García-Ferrer, M. Sánchez, M.A. Parra, M. Díaz, and P. Peña. 2001. Characterization of current management practices with high risk of nitrate contamination in agricultural areas of southern Spain Acta Hort. 563:73-80.

Greweling, T. 1976. Chemical analysis of plant tissue. Search and Agriculture, Agronomy 6. Cornell University, Ithaca, NY.

Hawkesford, M., W. Horst, T. Kichey, H. Lambers, J. Schjoerring, I.S. Møller, and P. White. 2012. Functions of macronutrients, p. 135-189. In Marschner, P. (ed.). Mineral nutrition of higher plants. 3rd Ed. Academic Press, Amsterdam, The Netherlands.

Huett, D.O. and G.R. Stewart. 1999. Timing in $\mathrm{N}-15$ fertiliser application, partitioning to reproductive and vegetative tissue, and nutrient removal by field-grown low-chill peaches in the subtropics. Austral. J. Agr. Res. 50:211215 . 
Jones, J.B. 1985. Soil testing and plant analysis: Guides to the fertilization of horticultural crops. Hort. Rev. 7:1-68.

Klein, I. and S.A. Weinbaum. 1984. Foliar application of urea to olive: Translocation of urea nitrogen as influenced by sink demand and nitrogen deficiency. J. Amer. Soc. Hort. Sci. 109:356-360.

Murphy, J. and J.P. Riley. 1962. A modify single solutions method for the determination of phosphate in natural waters. Anal. Chim. Acta 27:31-36.

Palmer, J.W. and G. Dryden. 2006. Fruit mineral removal rates from New Zealand apple (Malus domestica) orchards in the Nelson region. N. Z. J. Crop Hort. Sci. 34:27-32.

Parra, M.A., R. Fernández-Escobar, C. Navarro, and O. Arquero. 2003. Los suelos y la fertilización del olivar cultivado en zonas calcáreas. Mundi-Prensa, Madrid, Spain.

Restrepo-Díaz, H., M. Benlloch, C. Navarro, and R. Fernández-Escobar. 2008. Potassium fertilization of rainfed olive orchards. Sci. Hort 116:399-403.

Rochester, I.J. 2007. Nutrient uptake and export from an Australian cotton field. Nutr. Cycl. Agroecosyst. 77:213-223.
Rodrigues, M.A., I.Q. Ferreira, A.M. Claro, and M. Arrobas. 2012. Fertilizer recommendations for olive based upon nutrients removed in crop and pruning. Sci. Hort. 142:205-211.

Shear, C.B. and M. Faust. 1980. Nutritional ranges in deciduous tree fruits and nuts. Hort. Rev. 2:142-163.

Titus, J.S. and S.M. Kang. 1982. Nitrogen metabolism, translocation, and recycling in apple trees. Hort. Rev. 4:204-246.

Weinbaum, S.A., R.S. Johnson, and T.M. De Jong. 1992. Causes and consequences of overfertilization in orchards. HortTechnology 2:112-121. 